\title{
Ideological and Psychological Predictors of COVID-19-Related Collective Action, Opinions, and Health Compliance Across Three Nations
}

\author{
Becky L. Choma ${ }^{\mathrm{a}}$, Gordon Hodson ${ }^{\mathrm{b}}$, David Sumantry ${ }^{\mathrm{a}}$, Yaniv Hanoch ${ }^{\mathrm{c}}$, Michaela Gummerum ${ }^{\mathrm{d}}$ \\ [a] Department of Psychology, Ryerson University, Toronto, Ontario, Canada. [b] Department of Psychology, Brock University, St. Catharines, Ontario, Canada. \\ [c] Southampton Business School, University of Southampton, Southampton, United Kingdom. [d] Department of Psychology, University of Warwick, Coventry, \\ United Kingdom.
}

Journal of Social and Political Psychology, 2021, Vol. 9(1), 123-143, https://doi.org/10.5964/jspp.5585

Received: 2020-08-22 • Accepted: 2020-12-20 • Published (VoR): 2021-02-19

Handling Editor: Robin Gomila, Princeton University, Princeton, United States

Corresponding Author: Becky L. Choma, Department of Psychology, Ryerson University, 350 Victoria Street, Toronto, Ontario, Canada, M5B 2K3. E-mail: bchoma@ryerson.ca

Supplementary Materials: Data, Materials, Preregistration [see Index of Supplementary Materials]

\begin{abstract}
Until vaccines or treatments are widely available and used, behavioral change (e.g. social distancing) on an unparalleled collective scale is the chief way to curb the spread of COVID-19. Relying on ideology and collective action models as conceptual frameworks, in the present study the role of ideological and psychological factors in COVID-19-related opinions, health compliance behaviors, and collective action were examined in three countries. Results, examining country as a moderator, showed some politically conservative orientations, especially social dominance orientation, relate to less collective action, less support of measures to manage COVID-19, and lower compliance. Variables, including empathy for those affected by COVID-19 and group efficacy also predicted COVID-19related attitudes and behavior. Belief in science and perceived risk also emerged as key factors to impact compliance-related attitudes and behaviors. Implications for motivating collective compliance are discussed.
\end{abstract}

\section{Keywords}

political ideology, right-wing authoritarianism, social dominance orientation, empathy, group efficacy, collective action, COVID-19, health compliance behavior, belief in science, perceived risk

In December 2019, Chinese authorities reported cases of "pneumonia" with unknown origins (Taylor, 2020). Shortly after, scientists identified the cause as severe acute respiratory syndrome coronavirus 2 (SARS-CoV-2), which causes COVID-19 (Wee \& McNeill, 2020; WHO, 2020a). Until vaccines or treatment options are widely available and used, the chief way to slow the virus from spreading is through behavioral change on a massive collective scale. Hence, in the context of a global pandemic, health compliance is a collective act. China imposed strict quarantine orders (Zhong \& Mozur, 2020), ultimately curbing the spread (Lai et al., 2020). Western democracies also enacted measures; however, democracies inherently rely more heavily on citizen-motivated compliance. Therefore, social-psychological factors have a crucial role to play in reducing the spread of COVID-19, via their influence on health compliance-related attitudes and behavior. We investigate the role of ideological and psychological factors in shaping support for government-sanctioned actions (e.g. closing schools), health compliance behaviors (i.e. adherence to recommended actions like social distancing), and collective action in Canada, the U.S., and the UK.

Data were collected March 26-28, 2020. This was a time of elevated fear and uncertainty, as COVID-19 cases began to rise dramatically in western nations. U.S. President Trump had recently limited travel from Europe and closed U.S. schools (Villarreal, 2020), but was optimistic "the country [would] open up and [be] raring to go by Easter". Boris 
Johnson, the British Prime Minister, advised people as early as 17 March 2020 to remain home and socially distance. Of particular relevance, Johnson tested positive for the virus on 27 March. In Canada, Prime Minister Trudeau held daily news briefings from his home, self-isolating after his wife tested positive on March 12. Schools were closed in most of the country and those who could were asked to work from home. Thus, while the specific messages and styles of the political leaders differ, COVID-19 cases were rising dramatically and daily life was changing for each.

Of particular interest is how populations adapt and act collectively to shared problems. Collective actions are behaviors carried out by individuals - alone or in groups - "where the action is directed at improving the conditions of the group as a whole" (Wright, Taylor, \& Moghaddam, 1990, p. 995). Groups can be based on social categories or shared beliefs (Bliuc, McGarty, Reynolds, \& Muntele, 2007). Social identity, anger-based perceptions of group injustice, and group efficacy have received the most empirical attention and support as motivations for collective action (for meta-analyses see van Zomeren, Postmes, \& Spears, 2008; see also van Zomeren, 2013). These variables stem from three rich scholarly traditions (e.g. Crosby, 1976; Klandermans, 1984; Mummendey, Kessler, Klink, \& Mielke, 1999; Tajfel \& Turner, 1979). One of the most influential contemporary models, the Social Identity Model of Collective Action (van Zomeren et al., 2008), positions social identity as cultivating collective action mediated by way of injustice-based anger and group efficacy (for alternative models, see Thomas, McGarty, \& Mavor, 2009; Thomas, Mavor, \& McGarty, 2012).

Notwithstanding the utility of identity-, injustice-, or efficacy- based models, ideology as motivating collective action has been largely omitted in models of collective action (Becker, 2020). Ideology is uniquely positioned to explain collective action beyond specific group interests (Ho \& Kteily, 2020). The handful of researchers who have formerly considered ideology as motivating collective action have shown it predicts involvement in protests that challenge or uphold the existing system (e.g. Jost, Becker, Osborne, \& Badaan, 2017; Osborne, Jost, Becker, Badaan, \& Sibley, 2019), and that those endorsing both liberal or conservative ideologies engage in collective actions (e.g. Choma, Hodson, Jagayat, \& Hoffarth, 2020). Some have proposed that the content of the cause or issue is particularly relevant in the relation between political ideology and collective action (Becker, 2020; Choma et al., 2020). Before reviewing some of this research, we first clarify the definition of political ideology in the present research.

Political ideology can be conceptualized on a single liberal-conservative continuum or by two correlated, but separate dimensions (Duckitt, 2001; Jost, Glaser, Kruglanski, \& Sulloway, 2003): one typically encompasses social/cultural content, another status-relevant content. Two ideological beliefs, right-wing authoritarianism (RWA, Altemeyer, 1981) and social dominance orientation (SDO, Pratto, Sidanius, Stallworth, \& Malle, 1994), capture the social/cultural and status dimensions at the broader ideological level, respectively (Duckitt, 2001). RWA comprises preferences for punitive social control, uncritical support for perceived legitimate or established social authorities, and conventionalism (Altemeyer, 1981; Duckitt, Bizumic, Krauss, \& Heled, 2010). SDO concerns preferences for hierarchical social systems where higher status groups overpower lower status groups (Ho et al., 2015). RWA and SDO relate to common (e.g. generalized prejudice) and discrete outcomes (e.g. different facets of sexism) (Duckitt \& Sibley, 2009, 2017), with common outcomes often attributed to heightened perceived threat for those higher in RWA, and lack of concern or low empathy for those higher in SDO (McFarland, 2010; Onraet, Dhont, \& Van Hiel, 2014; Shaffer \& Duckitt, 2013; Sidanius et al., 2013).

Of the limited empirical studies conducted on ideological beliefs and collective action, both negative (Osborne, Yogeeswaran, \& Sibley, 2017; Weiner \& Federico, 2017) and positive associations (Saeri, Iyer, \& Louis, 2015) are reported. To reconcile this inconsistency, Choma and colleagues (2020) proposed that people across the political spectrum engage in collective action when a cause resonates with their values or worldviews. They found that those higher in RWA or SDO are less willing to engage in collective actions addressing climate change or racial inequality, and those higher in RWA are more willing to engage in collective actions addressing the moral breakdown of society (e.g., illicit drug use, pornography). Consistent with prevailing knowledge (Duckitt \& Sibley, 2017; McFarland, 2010; Onraet et al., 2014; Sidanius et al., 2013), fear-based threat or empathetic concern explained several of the ideology-collective action associations: less fear-based threat and less empathy explained the SDO-collective action link in moral breakdown, racial inequality, financial status (e.g. inequitable wealth distribution), and climate change domains, and less fear-based threat explained the RWA-collective action association in the climate change domain. These findings are also consistent with those higher in SDO being competitive and not risk averse. 
Public opinion polls suggest COVID-19 health compliance-related attitudes or behaviors might be tied to political ideology. In the U.S., Canada, and UK, those voting for more liberal- (vs. conservative) leaning parties perceive COVID-19 as a tangible threat and to a greater degree (Angus Reid Institute, 2020; Opinium, 2020; van Green \& Tyson, 2020). Other polls also reveal political divides in support for COVID-19 precautions, like closing schools, and limiting the size of public and private gatherings. For instance, notwithstanding overall high levels of support for social distancing among U.S. Republicans and Democrats in March 2020, support was higher among Democrats (van Green \& Tyson, 2020).

To summarize, feeling concerned for others, experiencing greater threat, and group efficacy act as catalysts of collective action (Choma et al., 2020; Osborne et al., 2019; van Zomeren et al., 2008). Moreover, there is a robust association between ideological beliefs, especially higher SDO, and lower empathy (e.g. Hodson, 2008; Sidanius et al., 2013). Polls have connected liberal political orientations with perceiving COVID-19 as more threatening (ARI, 2020; Opinium, 2020; van Green \& Tyson, 2020). Also, those who endorse liberal-leaning ideologies (e.g. lower SDO), are more likely to perceive a common fate with others, including those from disadvantaged groups (Ho, Kteily, \& Chen, 2017; McFarland et al., 2019). Together, these findings suggest that authoritarianism, SDO, or political conservatism, as well as lower threat, empathy, and group efficacy, might be allied with less willingness to engage in collective actions aimed at managing COVID-19, less support for precautions, and lower health compliance.

To provide a more comprehensive understanding of COVID-19 compliance-related attitudes and behaviors, we also explore key factors affecting health-related attitudes or behaviors identified in the health and decision-making literatures. Risk perceptions are implicated in health measures (Slovic, 1987); those who perceive more risk (e.g. in vaccination or cancer screening) are less likely to engage in preventative or intervention measures (Brewer et al., 2007; Kim et al., 2008). Perceived risk is tied to ideology: political conservatives perceive vaccines as riskier (Choma, Hanoch, Gummerum, \& Hodson, 2013) and hold less favourable vaccine attitudes (Baumgaertner, Carlisle, \& Justwan, 2018). Furthermore, data reveal that knowledge and health literacy are connected with participation in health prevention and intervention (e.g. Bendik, Mayo, \& Parker, 2011; Volk et al., 2016). For example, parents who are more knowledgeable about vaccines are more likely to vaccinate their children (Borràs et al., 2009). Similarly, health literacy, which indexes a person's ability to acquire, understand and process health-related information, relates positively to many health behaviours, including adherence to medical regimens (Miller, 2016), preventive health behaviors (Fernandez, Larson, \& Zikmund-Fisher, 2016), and gaining access to medical care (Levy \& Janke, 2016).

Belief or trust in authoritative bodies is also implicated in health compliance behaviors. Greater trust in medical or political authorities, for instance, predicted vaccination following the H1N1 pandemic (Gilles et al., 2011; van der Weerd et al., 2011). Right-wing ideologies are increasingly linked with lower trust of science more generally (Gauchat, 2012), especially environmental and health outcomes (Hamilton, Hartter, \& Saito, 2015; McCright, Dentzman, Charters, \& Dietz, 2013). Moreover, trust in governing-health bodies is associated with political orientation: liberals (vs. conservatives) trust information from Centers for Disease Control (CDC) more (85\% vs. 61\%) (Safford, Hamilton, \& Whitmore, 2017). Trust in information from governments depends, partly, on who is in power, with people more trusting of governments aligned with their political standing (Keele, 2005) (see Rutjens, Heine, Sutton, \& van Harreveld, 2018 for a review).

\section{The Present Research}

We examine predictors of collective actions aimed at managing COVID-19, opinions about measures to manage COVID-19, and health compliance behavior in Canada, the UK, and the U.S. These countries are English-speaking, democratic, experienced the rise of COVID-19 at similar times, and adopted both shared and divergent approaches to tackling the pandemic. The study protocol and hypotheses were pre-registered (see Choma, Hodson, Sumantry, Hanoch, \& Gummerum, 2021a); analyses were revised based on reviewer and associate editor feedback (see Choma, Hodson, Sumantry, Hanoch, \& Gummerum, 2021b). We expect higher authoritarianism (H1), SDO (H2), or political conservatism (vs. liberalism) (H3) to predict less collective action, less support for COVID-19 precautions, and less health compliance. Further, we expect higher threat, less concern for those affected by COVID-19, and higher group efficacy to predict higher collective action, more support for precautions, and higher compliance $(\mathrm{H} 4)$. We also examine 
higher personal impact, perceived risk, belief in science, trust of "liberal" authorities, health literacy, and greater knowledge about COVID-19, as relating to and predicting higher collective action, support for COVID-19 precautions, and higher compliance $(\mathrm{H} 5)^{1,2}$.

\section{Method}

\section{Participants and Procedure}

Power analyses recommended sample sizes of 256 for regression ( $G^{*}$ Power, Faul, Erdfelder, Buchner, \& Lang, 2009). A sensitivity analysis on the pooled sample $(n=1123)$ showed a $R^{2}$ change of .0085 and power of .80 could be detected. Data were collected between 26 March and 28 March 2020 using Qualtrics Panels: Canadian $(n=289)$, British $(n=308)$, and American $(n=526)$. Demographics are reported in Table 1.

\section{Table 1}

Demographic Characteristics by Sample

\begin{tabular}{lccc}
\hline Characteristic & Canada & UK & US \\
Age & $\boldsymbol{N}=\mathbf{2 8 9}$ & $\boldsymbol{N}=\mathbf{3 0 8}$ & $\boldsymbol{N}=\mathbf{5 2 6}$ \\
\hline Gender & $45.89(18.32)$ & $44.17(18.08)$ & $47.44(17.73)$ \\
\hline
\end{tabular}

Ethnicity (\%)

\begin{tabular}{lrrr} 
Arab & 2.8 & 1.9 & 0.6 \\
Black & 1.7 & 3.2 & 8.0 \\
Chinese & 8.0 & 1.9 & 2.1 \\
Filipino & 3.5 & 0.6 & 1.1 \\
Japanese & 1.0 & 0.6 & 1.0 \\
Korean & 0.0 & 0.3 & 0.2 \\
Latin American & 1.0 & 0.3 & 4.4 \\
South East Asian & 3.8 & 0.3 & 1.0 \\
South Asian & 6.9 & 3.6 & 3.0 \\
White & 66.1 & 84.1 & 75.3 \\
Other & 3.1 & 1.6 & 1.9 \\
\hline Religion (\%) & & & \\
Agnostic & 13.8 & 15.3 & 9.9 \\
Anglican & 5.5 & 11.0 & 2.1 \\
Atheist & 12.5 & 18.2 & 7.6 \\
Baptist & 3.5 & 1.9 & 10.1 \\
Catholic & 27.0 & 1.9 & 28.3 \\
Hindu & 4.2 & 0.0 & 1.1 \\
Jewish & 3.1 & 4.9 & 4.4 \\
Muslim & 5.5 & 17.2 & 2.3 \\
Protestant & 9.3 & 2.9 & 17.3 \\
United & 3.5 & 6.5 & 4.9 \\
Other & 11.4 & &
\end{tabular}

1) Cognitive reflection was named in the pre-registration; however, it was not included to shorten the survey.

2) In our original pre-registration we also proposed to evaluate whether authoritarianism, SDO, or conservatism (vs. liberalism) indirectly predict collective action, opinions, and compliance via threat, empathy, or group efficacy. Following recommendations from AE and one reviewer we removed the mediation component. 


\begin{tabular}{|c|c|c|c|}
\hline Characteristic & $\begin{array}{l}\text { Canada } \\
N=289\end{array}$ & $\begin{array}{c}\text { UK } \\
N=\mathbf{3 0 8}\end{array}$ & $\begin{array}{c}\text { US } \\
N=526\end{array}$ \\
\hline \multicolumn{4}{|l|}{ Education (\%) } \\
\hline Less than HS & 2.1 & 5.5 & 2.9 \\
\hline High School & 16.3 & 32.8 & 14.6 \\
\hline Some College & 23.2 & 20.1 & 24.9 \\
\hline College or Bach & 43.6 & 24.4 & 32.3 \\
\hline Master's & 11.4 & 14.0 & 19.4 \\
\hline Doctoral & 3.5 & 2.6 & 5.1 \\
\hline \multicolumn{4}{|l|}{ Income (\%) } \\
\hline Under $\$ 15 \mathrm{~K}$ & 5.5 & 12.3 & 8.4 \\
\hline$\$ 15 \mathrm{~K}-\$ 30 \mathrm{~K}$ & 15.6 & 26.3 & 12.4 \\
\hline$\$ 30 \mathrm{~K}-\$ 45 \mathrm{~K}$ & 11.8 & 21.1 & 9.3 \\
\hline$\$ 45 \mathrm{~K}-\$ 60 \mathrm{~K}$ & 13.8 & 18.8 & 12.0 \\
\hline$\$ 60 \mathrm{~K}-\$ 75 \mathrm{~K}$ & 12.8 & 11.4 & 11.8 \\
\hline$\$ 75 \mathrm{~K}-\$ 100 \mathrm{~K}$ & 19.7 & 7.1 & 17.3 \\
\hline Over $\$ 100 \mathrm{~K}$ & 20.8 & 2.6 & 28.3 \\
\hline
\end{tabular}

Note. The demographics reported here are based on samples excluding outliers. Original sample sizes were: $n=$ 311 (Canada), $n=320$ (UK), $n=550$ (US).

The samples were representative on age and gender, religiously and ethnically diverse [however, they were between $2.2 \%$ (UK) to $14.6 \%$ (US) over-representative of Whites] and represented a range of education levels and incomes. Participants completed measures of ideological beliefs and read a paragraph about COVID-19:

"COVID-19 is the infectious disease caused by the most recently discovered coronavirus. This new virus and disease were unknown before the outbreak began in Wuhan, China, in December 2019. COVID-19 cases have risen dramatically around the globe. The following pages ask how you feel about COVID-19 and your reactions to the COVID-19 pandemic."

Participants then completed measures of empathy, perceived threat, group efficacy, perceived personal impact, perceived risk, collective action intentions, opinions about measures to manage COVID-19, compliance with COVID-19 recommendations in the previous week, anticipated future compliance, belief in science, distrust of authorities, health literacy, COVID-19 knowledge, and demographic characteristics (attitudes towards Chinese people and people with COVID-19 were also measured, but are excluded because of space restrictions).

\section{Measures}

Unless stated otherwise, scores were created by averaging items. Higher scores denoted more of that variable.

\section{Ideological Predictor Variables}

Ideological beliefs - Two items from the traditionalism subscale of the ACT scale (Duckitt et al., 2010) assessed Authoritarianism ${ }^{3}$. Participants responded on a scale from 1-strongly disagree to 7-strongly agree. Eight items from the $\mathrm{SDO}_{7}$ (Ho et al., 2015) scale measured SDO. Participants responded on a scale from 1-strongly oppose to 7-strongly favor.

Political orientation - Participants indicated where they would place themselves on a scale from 1-extremely liberal to 11-extremely conservative.

3) Two items from each of the three ACT subscales (Duckitt et al., 2010) were administered to measure authoritarianism but reliabilities were very poor ( $\alpha$ 's .44 - .57). The correlations between the items for the authoritarianism items $\left(r^{\prime} s<.105\right)$ and conservatism items $\left(r^{\prime} s<.245\right)$ were atypically low. The correlations for the traditionalism items were more robust; therefore, these items were used to create an authoritarianism score. 


\section{Predictors From Collective Action Models}

Empathy/Concern for people affected by COVID-19 - Participants completed three items (e.g. "Please indicate the extent to which you feel concern for other people affected by COVID-19") based on Batson et al. (1997) scale, using a scale from 1-not at all to 7-very much.

Efficacy - Participants indicated the extent to which they agree on a scale from 1-not at all to 7-totally agree to a single item (van Zomeren, Postmes, Spears, \& Bettache, 2011): "I think together we can slow the spread of COVID-19 and save lives".

Threat - Participants indicated how they "feel right now about the COVID-19 pandemic" on a scale from 1-not at all to 7-extremely with respect to 10 items (modified from Choma et al., 2020). There were seven negative affect items (worried, agitated, distressed, afraid, concerned, scared, anxious) and three positive affect items (happy, calm, relaxed).

\section{COVID-19 Variables}

Opinions about measures to manage COVID-19 - Participants completed 11 items developed by the authors based on measures proposed or implemented by one or all of the countries sampled. Participants read "Several measures have been proposed and enacted to manage COVID-19 and its impact. Please indicate the degree to which you support or oppose each measure" from 1-totally opposed to 7-totally support. The measures included: release government funds to help individuals affected by COVID-19, close restaurants and bars, close public recreational centers, close schools and universities, close daycares, modify eligibility for employment insurance, release government funds to help businesses affected by COVID-19, cancel public transportation, ensuring that COVID-19 testing is free, track all COVID-19 cases, and close all businesses except for essential services.

Previous compliance behavior - Participants indicated the extent to which they engaged in 15 behaviors on a scale from 1-not at all to 7-all or almost all of the time. The behaviors were: prolonged hand-washing (20 seconds or more), especially after being in a public place; limited hand-to-face (i.e. not touching your face); covered coughs and sneezes (e.g. with disposable tissues or elbow); disinfected objects; avoided infected others; avoided crowded places; stayed home even if you felt well; stayed home if you feel unwell; kept kids home from school; avoided public transportation; avoided public spaces/events; had essentials (e.g. food) delivered to your home; shopped at non-peak hours; avoided physical contact with others, except those in your household; cancelled or prolonged travel. ${ }^{4}$

Anticipated future compliance - Participants indicated the extent to which they would be willing to engage in the following seven behaviors on a scale from 1-not at all willing to 7-extremely willing: self-isolate for 2 weeks, self-isolate for 1 month, social distance (stand 6 feet/2 meters away from those outside your household), get tested if you had symptoms, report to public health authorities if you had symptoms, receive a vaccination (should one become available) against COVID-19, and receive a vaccination against other related viruses. ${ }^{5}$

Collective action - Participants completed a 7-item scale modified to be specific to COVID-19 (Foster \& Matheson, 1995). Participants indicated how willing they would be to donate money to a charity, sign a petition, vote for a party or politician, write a letter to/email/tweet at the government, volunteer to be part of a group that raises awareness, and post on social media or write a letter to a newspaper, to support measures to manage COVID-19 on a scale from 1-not at all willing to 7-extremely willing.

\footnotetext{
4) "Purchased or worn a mask" and "stockpiled food" were also measured but excluded as these actions were not recommended by authorities at that time. Rather, several authoritative bodies, at that time, were advocating against the use of a mask (e.g. WHO) or stockpiling food.

5) Participants were also asked if they would be willing to pay for a vaccine and how much they would be willing to pay to receive a vaccine. In retrospect, the meaning of responses by participants was impossible to ascertain. A lower mean in Canada or the UK could indicate that people are less willing to pay because the government is expected to cover the cost. Given this ambiguity, these items were excluded.
} 


\section{Predictors From Health and Decision-Making Literature}

Risk - Participants completed five items modified from Ibuka, Chapman, Meyers, Li, and Galvani (2010). To tap Local Risk, participants responded to two items on a scale from $0 \%$ to $100 \%$ with $10 \%$ increments: "In your opinion, what is the likelihood that COVID-19 will reach your local community?" and "In your opinion, what is the likelihood that you will personally encounter somebody infected with COVID-19?” To measure Risk Severity, participants responded to two items: "In your opinion, how many people worldwide will die from COVID-19 during this outbreak" - responding on a 5-point scale from less than 1000 to more than 1,000,000; and "How likely do you think you are to contract COVID-19 within the next year?". These two items were standardized and then averaged. Finally, a single item, "What do you think the probability is that you will contract COVID-19" on a scale from $0 \%$ to $100 \%$ with $10 \%$ increments measured Personal Risk.

Personal impact - Two items modified from Rolison and Hanoch (2015) were used: "How serious would it be for you to contract COVID-19 in the next year" and "How serious would it be for you to contract COVID-19 within the next few days?" Participants responded on a scale from 1-not at all serious to 7-extremely serious. ${ }^{6}$

Belief in science - Participants completed five items from the Belief in Science scale (Farias, Newheiser, Kahane, \& de Toledo, 2013), responding from 1-strongly disagree to 7-strongly agree.

Distrust - Participants indicated the degree to which they would "trust the information given to [them] about COVID-19" by: the World Health Organization, Centers for Disease Control, Scientists, Public Health, College and Universities, Chinese Government, European Union, Mainstream Media, and respective heads of state (i.e. Justin Trudeau, Boris Johnson, Donald Trump) (modified Krause, Carley, Warren, Rupp, \& Graham, 2014). Participants responded on a scale from 1-completely, would not doubt to 4-do not believe them at all. Scores were created by averaging the items, except head of state was analysed separately.

Health literacy - Participants responded to three items of the eHEALS health literacy scale (Richtering et al., 2017) on a scale from 1-strongly disagree to 5-strongly agree.

COVID-19 knowledge - Three questions were developed by the researchers based on the Q\&A posted by the WHO (2020a). For each question, participants selected from three responses, one of which was correct. Responses were coded as correct or incorrect; scores were created by summing the correct responses. ${ }^{7}$

\section{Data Analysis}

Hypotheses were tested using a dataset pooled across countries in a regression framework (described as a no-pooling model in Gelman \& Hill, 2006). For each COVID-19 variable, a null model was created consisting only of covariates (demographics and country, using dummy codes). Next, the predictor of interest was added to the model, with unique models constructed for all predictor-COVID-19 variable pairs. This analytic approach allows for examination of relative predictive power for all relevant variables. Finally, in each model, the predictor x country interaction terms were added, allowing for examination of country-based differences in the predictor-COVID-19 variable relations, using the US sample as the dummy-coded baseline. We made no a-priori predictions for country-based differences; consequently, tests of these differences are exploratory.

6) A third item, "How confident are you that you could come up with $\$ 2000$ if an unexpected need arose within the next month" did not correlate with the first two items and was excluded from the scale.

7) There were originally four questions; however, due to errors in programming the fourth item had to be dropped. 


\section{Results}

\section{Descriptive Statistics and Correlations}

Data and R code are available on OSF (see Choma, Hodson, Sumantry, Hanoch, \& Gummerum, 2021c). Means, standard deviations, and reliabilities on the pooled data are shown in Table 2. Correlations with COVID-19 variables are also shown in Table 2 (correlations amongst all variables in Appendix 1 on OSF, see Choma, Hodson, Sumantry, Hanoch, \& Gummerum, 2021d). Higher authoritarianism or SDO related to opposition to COVID-19 measures and lower future compliance. Higher SDO (but not authoritarianism) related to lower past compliance. Neither authoritarianism nor SDO related to collective action. Associations with political orientation were not statistically significant. Threat, empathy, and efficacy related to support for COVID-19 measures, greater compliance, and higher collective action. Perceiving greater local or personal risk, higher risk severity, higher perceived personal impact, higher belief in science, higher health literacy, and being more knowledgeable related to support for COVID-measures, greater past and future compliance, and higher collective action, with the exception of knowledge, which did not relate to collective action. Across countries, trust in the respective political leader did not relate to support for COVID-19 measures, compliance, or collective action.

Table 2

Descriptive Statistics and Correlations With COVID-19 Variables on Pooled Data

\begin{tabular}{|c|c|c|c|c|c|c|c|}
\hline Variable & $M$ & $S D$ & $\alpha$ & $\begin{array}{c}\text { Compliance } \\
\text { Opinion }\end{array}$ & $\begin{array}{c}\text { Compliance } \\
\text { Past }\end{array}$ & $\begin{array}{c}\text { Compliance } \\
\text { Future }\end{array}$ & $\begin{array}{c}\text { Collective } \\
\text { Action }\end{array}$ \\
\hline \multicolumn{8}{|l|}{ COVID-19 Variables } \\
\hline Compliance Opinion & 5.92 & 1.01 & .91 & & & & \\
\hline Compliance Past & 5.99 & 0.92 & .90 & $.643^{* * *}$ & & & \\
\hline Compliance Future & 6.27 & 0.92 & .79 & $.684^{* * *}$ & $.666^{* * *}$ & & \\
\hline Collective Action & 4.97 & 1.39 & .85 & $.312^{* * *}$ & $.354^{* * *}$ & $.282^{* * *}$ & \\
\hline \multicolumn{8}{|c|}{ Collective Action Model Predictors } \\
\hline Threat & 4.86 & 1.18 & .87 & $.360^{* * *}$ & $.347^{* * *}$ & $.296^{* * *}$ & $.311^{* * *}$ \\
\hline Empathy & 6.06 & 1.09 & .87 & $.644^{* * *}$ & $.609^{* * *}$ & $.612^{* * *}$ & $.338^{* * *}$ \\
\hline Efficacy & 6.07 & 1.21 & - & $.570^{\star * *}$ & $.493^{* * *}$ & $.523^{\star * *}$ & $.269^{* * *}$ \\
\hline \multicolumn{8}{|c|}{ Health and Decision-Making Predictors } \\
\hline Local Risk & 6.70 & 2.39 & - & $.289^{* * *}$ & $.245^{* * *}$ & $.310^{* * *}$ & $.138^{* * *}$ \\
\hline Personal Risk & 0.02 & 0.93 & - & $.133^{* * *}$ & $.139^{* * *}$ & $.090^{* *}$ & $.222^{* * *}$ \\
\hline Risk Severity & 3.48 & 1.01 & - & $.245^{* * *}$ & $.189^{* * *}$ & $.242^{* * *}$ & $.058^{*}$ \\
\hline Personal Impact & 5.47 & 1.49 & - & $.368^{* * *}$ & $.365^{* * *}$ & $.364^{* * *}$ & $.244^{* * *}$ \\
\hline Belief in Science & 4.80 & 1.35 & .92 & $.313^{* * *}$ & $.308^{* * *}$ & $.305^{* * *}$ & $.353^{* * *}$ \\
\hline Distrust & 2.25 & 0.52 & .83 & $-.277^{* * *}$ & $-.187^{* * *}$ & $-.229^{* * *}$ & $-.207^{* * *}$ \\
\hline Distrust in PM/Pres & 2.53 & 0.98 & - & -.038 & -.023 & -.026 & -.029 \\
\hline Health Literacy & 3.54 & 0.92 & .81 & $.242^{\star * *}$ & $.282^{* * *}$ & $.197^{* * *}$ & $.205^{* * *}$ \\
\hline COVID Knowledge & 2.86 & 0.79 & - & $.213^{* * *}$ & $.184^{* * *}$ & $.225^{* * *}$ & .008 \\
\hline \multicolumn{8}{|l|}{ Ideological Predictors } \\
\hline Authoritarianism & 3.26 & 1.73 & - & $-.146^{* * *}$ & -.049 & $-.153^{* * *}$ & .038 \\
\hline SDO & 3.12 & 1.09 & .79 & $-.299^{* * *}$ & $-.189^{* * *}$ & $-.259^{* * *}$ & -.015 \\
\hline Lib-Cons & 6.11 & 2.98 & - & -.020 & .042 & .002 & -.029 \\
\hline
\end{tabular}

Note. "-" indicates a single or two item scale. For values by sample, see Appendix 2a (Word) or 2b (Excel file) on OSF (see Choma et al., 2021d). $p<.05 .{ }^{* *} p<.01 .{ }^{* * *} p<.001$

Correlations between ideology with the other predictor variables are in Table 3. Authoritarianism and SDO related negatively to perceiving COVID-19 as threatening, empathy for those affected, and efficacy. Authoritarianism and 
SDO related negatively to the health and decision-making variables, with some exceptions: authoritarianism related positively to personal impact and distrust; SDO related positively to personal risk and was unrelated to belief in science. Higher conservatism related negatively to perceived threat, belief in science, and distrust of head of state, and positively to personal impact and distrust, but was unrelated to the other variables.

Table 3

Correlations Between Ideology Variables With Other Predictor Variables on Pooled Data

\begin{tabular}{lccc}
\hline Variable & Auth & SDO & Lib-Cons \\
\hline Auth & - & $.249^{* * *}$ & $.325^{* * *}$ \\
SDO & - & - & $.354^{* * *}$ \\
Lib-Cons & - & - & - \\
Threat & $-.051^{*}$ & $-.076^{* *}$ & $-.073^{* *}$ \\
Empathy & $-.074^{* *}$ & $-.329^{* * *}$ & .006 \\
Efficacy & $-.127^{* * *}$ & $-.310^{* * *}$ & .008 \\
Local Risk & $-.209^{* * *}$ & $-.113^{* * *}$ & .004 \\
Pers Risk & $-.058^{*}$ & $.077^{* *}$ & .035 \\
Risk Sever & $-.122^{* * *}$ & $-.102^{* * *}$ & -.035 \\
Pers Impact & $.061^{*}$ & $-.052^{*}$ & $.051^{*}$ \\
BIS & $-.220^{* * *}$ & -.040 & $-.078^{* *}$ \\
DIS & $.197^{* * *}$ & $-.164^{* * *}$ & $.160^{* * *}$ \\
DIS HOS & $-.154^{* * *}$ & $-.213^{* * *}$ & $-.213^{* * *}$ \\
Health Lit & $-.062^{*}$ & $-.076^{* *}$ & -.016 \\
Knowledge & $-.155^{* * *}$ & $-.144^{* * *}$ & -.038 \\
\hline
\end{tabular}

Note. Auth = authoritarianism; SDO = social dominance orientation; Lib-Cons = political liberalism vs. conservatism; Pers = Personal; BIS = belief in science; DIS = distrust; DIS HOS = distrust in head of state; Health lit = Health literacy; Knowledge = COVID-19 Knowledge. For correlations by sample, see Appendix 2a or 2b on OSF (see Choma et al., 2021d).

$p<.05 .{ }^{* *} p<.01 .{ }^{* * *} p<.001$.

\section{Regressions}

Regression results are shown in Table 4a, Table 4b, and Table 4c, with simple slopes for significant interactions reported in Table 5a, Table 5b, and Table 5c. The variance accounted for by the demographic variables is shown in the first line of Table 4a only for brevity. The results for each demographic variable can be found in a spreadsheet in Appendix 3 on OSF (see Choma et al., 2021d).

Table 4a

Unstandardized Regression Estimates for Ideology Variables Predicting COVID-19 Variables

\begin{tabular}{lrrrr}
\hline Predictor & Compliance Opinion & Compliance Past & Compliance Future & Collective Action \\
\hline Demo-only $R_{\text {adj }}^{2}$ & .086 & .100 & .146 \\
\hline Auth. & $-0.08^{* * *}[-0.12,-0.04]$ & $-0.02[-0.05,0.02]$ & $-0.06^{* *}[-0.09,-0.02]$ & .030 \\
$R_{\text {adj }}^{2}$ & .100 & .100 & .155 & $0.01[-0.05,0.06]$ \\
US sample & $-0.09^{* * *}[-0.14,-0.04]$ & $-0.03[-0.07,0.02]$ & $-0.07^{* *}[-0.11,-0.02]$ & -029 \\
US vs Canada & $0.09^{*}[0.01,0.16]$ & $0.04[-0.03,0.11]$ & $0.07^{*}[0.00,0.14]$ & $-0.08^{*}[-0.15,-0.00]$ \\
US vs UK & $-0.05[-0.13,0.04]$ & $-0.02[-0.09,0.06]$ & $-0.05[-0.12,0.03]$ & $0.15^{*}[0.03,0.26]$ \\
$R_{\text {adj }}^{2}$ & .106 & .100 & .161 & $0.16^{*}[0.04,0.29]$
\end{tabular}




\begin{tabular}{|c|c|c|c|c|}
\hline Predictor & Compliance Opinion & Compliance Past & Compliance Future & Collective Action \\
\hline SDO & $-0.25^{* * *}[-0.30,-0.20]$ & $-0.13^{* * *}[-0.18,-0.08]$ & $-0.19^{* * *}[-0.24,-0.14]$ & $-0.06[-0.14,0.02]$ \\
\hline$R_{\mathrm{adj}}^{2}$ & .153 & .122 & .190 & .031 \\
\hline US sample & $-0.28^{* * *}[-0.36,-0.21]$ & $-0.15^{* * *}[-0.22,-0.08]$ & $-0.20^{* * *}[-0.27,-0.13]$ & $-0.09[-0.20,0.02]$ \\
\hline US vs Canada & $0.13^{*}[0.00,0.26]$ & $0.11[-0.01,0.23]$ & $0.12[-0.00,0.23]$ & $0.06[-0.13,0.25]$ \\
\hline US $v s \mathrm{UK}$ & $0.01[-0.11,0.13]$ & $-0.04[-0.16,0.07]$ & $-0.06[-0.18,0.05]$ & $0.06[-0.13,0.25]$ \\
\hline$R_{\mathrm{adj}}^{2}$ & .155 & .125 & .194 & .030 \\
\hline Lib-Cons & $-0.00[-0.02,0.02]$ & $0.01[-0.01,0.03]$ & $0.01[-0.01,0.03]$ & $-0.02[-0.05,0.01]$ \\
\hline$R_{\mathrm{adj}}^{2}$ & .086 & .101 & .146 & .030 \\
\hline US sample & $-0.01[-0.04,0.02]$ & $0.01[-0.02,0.03]$ & $-0.00[-0.03,0.02]$ & $-0.04^{*}[-0.09,-0.00]$ \\
\hline US vs Canada & $-0.01[-0.06,0.04]$ & $-0.01[-0.06,0.03]$ & $-0.01[-0.06,0.03]$ & $0.02[-0.05,0.09]$ \\
\hline US $v s \mathrm{UK}$ & $0.04[-0.01,0.09]$ & $0.05^{*}[0.00,0.09]$ & $0.05^{*}[0.00,0.09]$ & $0.10^{* *}[0.03,0.17]$ \\
\hline$R_{\mathrm{adj}}^{2}$ & .087 & .105 & .149 & .035 \\
\hline
\end{tabular}

Table 4b

Unstandardized Regression Estimates for Collective Action Model Variables Predicting COVID-19 Variables

\begin{tabular}{|c|c|c|c|c|}
\hline Predictor & Compliance Opinion & Compliance Past & Compliance Future & Collective Action \\
\hline Empathy & $0.58^{* * *}[0.54,0.62]$ & $0.49^{* * *}[0.44,0.53]$ & $0.47^{* * *}[0.43,0.52]$ & $0.49^{* * *}[0.41,0.57]$ \\
\hline$R_{\mathrm{adj}}^{2}$ & .434 & .394 & .413 & .158 \\
\hline US sample & $0.66^{* * *}[0.60,0.72]$ & $0.56^{* * *}[0.50,0.61]$ & $0.53^{* * *}[0.47,0.59]$ & $0.51^{* * *}[0.40,0.62]$ \\
\hline US vs Canada & $-0.29^{* * *}[-0.40,-0.18]$ & $-0.26^{* * *}[-0.37,-0.16]$ & $-0.27^{\star * *}[-0.38,-0.16]$ & $-0.10[-0.29,0.10]$ \\
\hline US $v s \mathrm{UK}$ & $-0.07[-0.17,0.03]$ & $-0.04[-0.14,0.05]$ & $-0.00[-0.10,0.10]$ & $-0.00[-0.17,0.17]$ \\
\hline$R_{\text {adj }}^{2}$ & .447 & .407 & .427 & .158 \\
\hline Group Efficacy & $0.43^{\star \star \star}[0.39,0.48]$ & $0.33^{* * *}[0.29,0.37]$ & $0.36^{* * \star}[0.31,0.40]$ & $0.33^{* * *}[0.26,0.40]$ \\
\hline$R_{\text {adj }}^{2}$ & .335 & .269 & .342 & .102 \\
\hline US sample & $0.46^{* * *}[0.41,0.52]$ & $0.34^{* * *}[0.28,0.39]$ & $0.41^{* * *}[0.35,0.47]$ & $0.33^{* * *}[0.24,0.43]$ \\
\hline US vs Canada & $-0.28^{* * *}[-0.40,-0.16]$ & $-0.17^{* *}[-0.28,-0.05]$ & $-0.31^{* * *}[-0.42,-0.20]$ & $-0.03[-0.23,0.16]$ \\
\hline US $v s \mathrm{UK}$ & $0.05[-0.05,0.14]$ & $0.05[-0.04,0.14]$ & $-0.01[-0.10,0.08]$ & $-0.01[-0.17,0.14]$ \\
\hline$R_{\text {adj }}^{2}$ & .351 & .277 & .362 & .101 \\
\hline Threat & $0.28^{* * *}[0.23,0.33]$ & $0.24^{* * *}[0.20,0.28]$ & $0.18^{* * *}[0.14,0.23]$ & $0.35^{* * *}[0.28,0.42]$ \\
\hline$R_{\mathrm{adj}}^{2}$ & .188 & .189 & .198 & .110 \\
\hline US sample & $0.33^{* * *}[0.26,0.39]$ & $0.27^{* * *}[0.21,0.33]$ & $0.22^{* * *}[0.16,0.29]$ & $0.39^{* * *}[0.29,0.49]$ \\
\hline US vs Canada & $-0.20^{* *}[-0.31,-0.08]$ & $-0.14^{* *}[-0.25,-0.04]$ & $-0.14^{*}[-0.25,-0.03]$ & $-0.12[-0.29,0.05]$ \\
\hline US $v s \mathrm{UK}$ & $0.01[-0.10,0.13]$ & $0.02[-0.08,0.13]$ & $-0.02[-0.13,0.09]$ & $-0.03[-0.20,0.14]$ \\
\hline$R_{\text {adj }}^{2}$ & .197 & .195 & .202 & .110 \\
\hline
\end{tabular}


Table 4c

Unstandardized Regression Estimates for Health and Decision-Making Variables Predicting COVID-19 Variables

\begin{tabular}{|c|c|c|c|c|}
\hline Predictor & Compliance Opinion & Compliance Past & Compliance Future & Collective Action \\
\hline Local Risk & $0.11^{* * *}[0.09,0.13]$ & $0.08^{* * *}[0.06,0.10]$ & $0.10^{* * *}[0.08,0.12]$ & $0.09^{* * *}[0.05,0.13]$ \\
\hline$R_{\mathrm{adj}}^{2}$ & .151 & .139 & .208 & .052 \\
\hline US sample & $0.15^{* * *}[0.11,0.18]$ & $0.11^{* * *}[0.08,0.14]$ & $0.13^{* * *}[0.10,0.17]$ & $0.16^{* * *}[0.10,0.21]$ \\
\hline US vs Canada & $-0.12^{* * *}[-0.17,-0.06]$ & $-0.12^{* * *}[-0.17,-0.07]$ & $-0.08^{* *}[-0.13,-0.02]$ & $-0.18^{* * *}[-0.27,-0.09]$ \\
\hline US $v s \mathrm{UK}$ & $-0.02[-0.07,0.04]$ & $-0.00[-0.05,0.05]$ & $-0.04[-0.10,0.01]$ & $-0.06[-0.14,0.02]$ \\
\hline$R_{\mathrm{adj}}^{2}$ & .162 & .155 & .213 & .065 \\
\hline Personal Risk & $0.15^{* * *}[0.09,0.22]$ & $0.14^{* * *}[0.08,0.19]$ & $0.10^{\star \star}[0.04,0.16]$ & $0.33^{* * *}[0.24,0.41]$ \\
\hline$R_{\mathrm{adj}}^{2}$ & .106 & .119 & .155 & .076 \\
\hline US sample & $0.17^{* * *}[0.08,0.27]$ & $0.14^{* *}[0.05,0.22]$ & $0.08[-0.01,0.16]$ & $0.45^{* * *}[0.32,0.58]$ \\
\hline US vs Canada & $-0.10[-0.26,0.05]$ & $-0.08[-0.21,0.06]$ & $0.02[-0.12,0.16]$ & $-0.31^{* *}[-0.53,-0.10]$ \\
\hline US $v s \mathrm{UK}$ & $0.03[-0.12,0.17]$ & $0.07[-0.06,0.21]$ & $0.05[-0.09,0.19]$ & $-0.14[-0.36,0.07]$ \\
\hline$R_{\mathrm{adj}}^{2}$ & .106 & .120 & .153 & .081 \\
\hline Risk Severity & $0.19^{* * *}[0.14,0.25]$ & $0.12^{* * *}[0.07,0.17]$ & $0.15^{* * *}[0.10,0.21]$ & $0.07[-0.02,0.16]$ \\
\hline$R_{\mathrm{adj}}^{2}$ & .121 & .112 & .170 & .031 \\
\hline US sample & $0.17^{* * *}[0.09,0.26]$ & $0.09^{*}[0.01,0.17]$ & $0.15^{* * *}[0.06,0.23]$ & $0.15^{*}[0.02,0.27]$ \\
\hline US vs Canada & $-0.06[-0.21,0.09]$ & $-0.02[-0.16,0.12]$ & $-0.02[-0.16,0.12]$ & $-0.25^{*}[-0.48,-0.03]$ \\
\hline US $v s \mathrm{UK}$ & $0.10[-0.03,0.23]$ & $0.10[-0.02,0.22]$ & $0.04[-0.09,0.16]$ & $-0.07[-0.27,0.12]$ \\
\hline$R_{\mathrm{adj}}^{2}$ & .123 & .113 & .168 & .034 \\
\hline Personal Impact & $0.23^{* * *}[0.19,0.26]$ & $0.20^{* * *}[0.17,0.23]$ & $0.20^{\star * *}[0.17,0.24]$ & $0.22^{* * *}[0.17,0.28]$ \\
\hline$R_{\mathrm{adj}}^{2}$ & .193 & .201 & .245 & .083 \\
\hline US sample & $0.30^{* * *}[0.25,0.36]$ & $0.28^{* * *}[0.23,0.33]$ & $0.29^{* * *}[0.24,0.34]$ & $0.28^{* * *}[0.20,0.36]$ \\
\hline US vs Canada & $-0.22^{* * *}[-0.31,-0.13]$ & $-0.21^{* * *}[-0.29,-0.13]$ & $-0.23^{* * *}[-0.31,-0.14]$ & $-0.09[-0.22,0.05]$ \\
\hline US $v s \mathrm{UK}$ & $-0.07[-0.15,0.02]$ & $-0.07[-0.15,0.01]$ & $-0.09^{*}[-0.17,-0.01]$ & $-0.12[-0.25,0.01]$ \\
\hline$R_{\mathrm{adj}}^{2}$ & .209 & .219 & .266 & .084 \\
\hline $\mathrm{BiS}$ & $0.24^{* * *}[0.20,0.28]$ & $0.22^{* * *}[0.18,0.26]$ & $0.21^{* * *}[0.17,0.24]$ & $0.37^{* * *}[0.31,0.43]$ \\
\hline$R_{\mathrm{adj}}^{2}$ & .185 & .199 & .231 & .152 \\
\hline US sample & $0.28^{* * *}[0.22,0.33]$ & $0.25^{\star \star *}[0.20,0.30]$ & $0.24^{* * *}[0.19,0.29]$ & $0.44^{* * *}[0.36,0.52]$ \\
\hline US vs Canada & $-0.15^{* *}[-0.25,-0.05]$ & $-0.13^{* *}[-0.22,-0.04]$ & $-0.13^{* *}[-0.23,-0.04]$ & $-0.20^{* *}[-0.35,-0.06]$ \\
\hline US $v s \mathrm{UK}$ & $0.01[-0.09,0.11]$ & $0.02[-0.07,0.11]$ & $-0.00[-0.10,0.09]$ & $-0.08[-0.23,0.07]$ \\
\hline$R_{\text {adj }}^{2}$ & .191 & .205 & .236 & .156 \\
\hline Distrust & $-0.50^{* * *}[-0.61,-0.39]$ & $-0.31^{* * *}[-0.41,-0.21]$ & $-0.34^{* * *}[-0.45,-0.24]$ & $-0.54^{* * *}[-0.70,-0.38]$ \\
\hline$R_{\mathrm{adj}}^{2}$ & .150 & .129 & .183 & .068 \\
\hline US sample & $-0.52^{* * *}[-0.67,-0.37]$ & $-0.30^{* * *}[-0.44,-0.16]$ & $-0.31^{* * *}[-0.45,-0.17]$ & $-0.76^{* * *}[-0.98,-0.53]$ \\
\hline US vs Canada & $0.19[-0.08,0.46]$ & $0.15[-0.10,0.40]$ & $0.02[-0.23,0.28]$ & $0.67^{* *}[0.27,1.07]$ \\
\hline US $v s \mathrm{UK}$ & $-0.09[-0.35,0.18]$ & $-0.16[-0.41,0.09]$ & $-0.16[-0.41,0.10]$ & $0.22[-0.17,0.62]$ \\
\hline$R_{\text {adj }}^{2}$ & .151 & .131 & .183 & .076 \\
\hline Distrust Lead. & $-0.01[-0.07,0.06]$ & $0.00[-0.05,0.06]$ & $0.01[-0.05,0.07]$ & $-0.01[-0.10,0.08]$ \\
\hline$R_{\mathrm{adj}}^{2}$ & .085 & .101 & .146 & .030 \\
\hline US sample & $0.17^{* * *}[0.08,0.25]$ & $0.13^{* *}[0.05,0.20]$ & $0.14^{* * *}[0.06,0.22]$ & $0.13^{*}[0.00,0.25]$ \\
\hline US vs Canada & $-0.36^{* * *}[-0.52,-0.20]$ & $-0.23^{* *}[-0.37,-0.09]$ & $-0.30^{* * *}[-0.45,-0.16]$ & $-0.20[-0.42,0.03]$ \\
\hline US $v s \mathrm{UK}$ & $-0.41^{* * *}[-0.57,-0.26]$ & $-0.33^{* * *}[-0.47,-0.20]$ & $-0.30^{* * *}[-0.44,-0.15]$ & $-0.40^{* * *}[-0.63,-0.18]$ \\
\hline$R_{\mathrm{adj}}^{2}$ & .115 & .121 & .167 & .041 \\
\hline
\end{tabular}




\begin{tabular}{|c|c|c|c|c|}
\hline Predictor & Compliance Opinion & Compliance Past & Compliance Future & Collective Action \\
\hline Health Literacy & $0.24^{* * *}[0.18,0.30]$ & $0.26^{\star \star \star}[0.20,0.31]$ & $0.18^{* * *}[0.12,0.24]$ & $0.32^{* * *}[0.23,0.42]$ \\
\hline$R_{\mathrm{adj}}^{2}$ & .130 & .162 & .176 & .071 \\
\hline US sample & $0.28^{* * *}[0.19,0.38]$ & $0.33^{* * *}[0.25,0.41]$ & $0.24^{* * *}[0.16,0.33]$ & $0.52^{* * *}[0.39,0.66]$ \\
\hline US vs Canada & $-0.19^{*}[-0.36,-0.02]$ & $-0.20^{*}[-0.35,-0.05]$ & $-0.13[-0.29,0.03]$ & $-0.42^{* *}[-0.67,-0.17]$ \\
\hline US $v s \mathrm{UK}$ & $-0.03[-0.17,0.11]$ & $-0.10[-0.23,0.03]$ & $-0.11[-0.24,0.02]$ & $-0.36^{* *}[-0.57,-0.16]$ \\
\hline$R_{\mathrm{adj}}^{2}$ & .132 & .166 & .178 & .085 \\
\hline COVID Knowledge & $0.18^{* * *}[0.11,0.26]$ & $0.14^{* \star \star}[0.07,0.20]$ & $0.18^{* * *}[0.11,0.25]$ & $0.00[-0.11,0.12]$ \\
\hline$R_{\mathrm{adj}}^{2}$ & .104 & .112 & .167 & .029 \\
\hline US sample & $0.27^{* * *}[0.16,0.38]$ & $0.22^{* \star *}[0.12,0.32]$ & $0.22^{* * *}[0.12,0.32]$ & $0.01[-0.15,0.18]$ \\
\hline US vs Canada & $-0.28^{* *}[-0.47,-0.09]$ & $-0.25^{* *}[-0.42,-0.08]$ & $-0.17[-0.34,0.00]$ & $-0.02[-0.29,0.26]$ \\
\hline US $v s \mathrm{UK}$ & $-0.07[-0.25,0.10]$ & $-0.09[-0.25,0.07]$ & $0.02[-0.15,0.18]$ & $-0.02[-0.28,0.24]$ \\
\hline$R_{\mathrm{adj}}^{2}$ & .110 & .117 & .169 & .027 \\
\hline
\end{tabular}

Note. Auth = authoritarianism; SDO = social dominance orientation; Lib-Cons = political liberalism vs. conservatism, BiS = belief in science. Each predictor was examined separately, controlling for gender, religion, education, and ethnicity. Base models represent the effect of the predictor on the dependent variable for the US context. Interaction effects (i.e. US vs. Canada; US vs. UK) represent difference between the given country and the US sample for the predictor-DV relation.

$p<.05 .{ }^{* *} p<.01 .{ }^{* * *} p<.001$.

\section{Table 5a}

Unstandardized Simple Slopes by Country for Ideology Variables Predicting COVID-19 Variables

\begin{tabular}{|c|c|c|c|c|}
\hline Predictor & Compliance Opinion & Compliance Past & Compliance Future & Collective Action \\
\hline \multicolumn{5}{|l|}{ Auth. } \\
\hline US & $-0.09^{* * *}[-0.14,-0.04]$ & - & $-0.07^{* *}[-0.11,-0.02]$ & $-0.08^{*}[-0.15,-0.00]$ \\
\hline Canada & $-0.01[-0.07,0.06]$ & - & $0.00[-0.05,0.06]$ & $0.07[-0.02,0.17]$ \\
\hline UK & - & - & - & $0.09[-0.02,0.19]$ \\
\hline \multicolumn{5}{|l|}{ SDO } \\
\hline US & $-0.28^{* * *}[-0.36,-0.21]$ & - & - & - \\
\hline Canada & $-0.15^{* *}[-0.26,-0.05]$ & - & - & - \\
\hline UK & - & - & - & - \\
\hline \multicolumn{5}{|l|}{ Lib-Cons } \\
\hline US & - & $0.01[-0.02,0.03]$ & $-0.00[-0.03,0.02]$ & $-0.04^{*}[-0.09,-0.00]$ \\
\hline Canada & - & - & - & - \\
\hline UK & - & $0.05^{* *}[0.02,0.09]$ & $0.05^{*}[0.01,0.08]$ & $0.05[-0.01,0.11]$ \\
\hline
\end{tabular}


Table 5b

Unstandardized Simple Slopes by Country for Collective Action Model Variables Predicting COVID-19 Variables

\begin{tabular}{|c|c|c|c|c|}
\hline Predictor & Compliance Opinion & Compliance Past & Compliance Future & Collective Action \\
\hline \multicolumn{5}{|l|}{ Empathy } \\
\hline US & $0.66^{* * *}[0.60,0.72]$ & $0.56^{* * *}[0.50,0.61]$ & $0.53^{* * *}[0.47,0.59]$ & - \\
\hline Canada & $0.37^{* * *}[0.28,0.47]$ & $0.29^{* * *}[0.20,0.38]$ & $0.26^{* * *}[0.17,0.35]$ & - \\
\hline UK & - & - & - & - \\
\hline \multicolumn{5}{|c|}{ Group Efficacy } \\
\hline US & $0.46^{* * *}[0.41,0.52]$ & $0.34^{* * *}[0.28,0.39]$ & $0.41^{* * *}[0.35,0.47]$ & - \\
\hline Canada & $0.18^{* * *}[0.08,0.29]$ & $0.17^{* * *}[0.07,0.27]$ & $0.10^{*}[0.00,0.20]$ & - \\
\hline UK & - & - & - & - \\
\hline \multicolumn{5}{|l|}{ Threat } \\
\hline US & $0.33^{* * *}[0.26,0.39]$ & $0.27^{* * *}[0.21,0.33]$ & $0.22^{* * *}[0.16,0.29]$ & - \\
\hline Canada & $0.13^{* *}[0.03,0.22]$ & $0.13^{* *}[0.04,0.21]$ & $0.09[-0.00,0.18]$ & - \\
\hline UK & - & - & - & - \\
\hline
\end{tabular}

Table 5c

Unstandardized Simple Slopes by Country for Health and Decision-Making Variables Predicting COVID-19 Variables

\begin{tabular}{|c|c|c|c|c|}
\hline Predictor & Compliance Opinion & Compliance Past & Compliance Future & Collective Action \\
\hline \multicolumn{5}{|l|}{ Local Risk } \\
\hline US & $0.15^{* * *}[0.11,0.18]$ & $0.11^{* * *}[0.08,0.14]$ & $0.13^{* * *}[0.10,0.17]$ & $0.16^{* * *}[0.10,0.21]$ \\
\hline Canada & $0.03[-0.02,0.08]$ & $-0.01[-0.05,0.03]$ & $0.05^{*}[0.01,0.10]$ & $-0.02[-0.09,0.05]$ \\
\hline UK & - & - & - & - \\
\hline \multicolumn{5}{|c|}{ Personal Risk } \\
\hline US & - & - & - & $0.45^{* * *}[0.32,0.58]$ \\
\hline Canada & - & - & - & $0.14[-0.04,0.31]$ \\
\hline UK & - & - & - & - \\
\hline \multicolumn{5}{|c|}{ Risk Severity } \\
\hline US & - & - & - & $0.15^{*}[0.02,0.27]$ \\
\hline Canada & - & - & - & $-0.11[-0.29,0.08]$ \\
\hline UK & - & - & - & - \\
\hline \multicolumn{5}{|c|}{ Personal Impact } \\
\hline US & $0.30^{* * *}[0.25,0.36]$ & $0.28^{* * *}[0.23,0.33]$ & $0.29^{* * *}[0.24,0.34]$ & - \\
\hline Canada & $0.08^{*}[0.01,0.15]$ & $0.07^{*}[0.00,0.13]$ & $0.06[-0.01,0.13]$ & - \\
\hline UK & - & - & $0.20^{* * *}[0.13,0.26]$ & - \\
\hline \multicolumn{5}{|l|}{$\mathrm{BiS}$} \\
\hline US & $0.28^{* * *}[0.22,0.33]$ & $0.25^{* * *}[0.20,0.30]$ & $0.24^{* * *}[0.19,0.29]$ & $0.44^{* * *}[0.36,0.52]$ \\
\hline Canada & $0.13^{* *}[0.05,0.21]$ & $0.12^{* *}[0.05,0.20]$ & $0.11^{* *}[0.03,0.18]$ & $0.24^{* * *}[0.11,0.36]$ \\
\hline UK & - & - & - & - \\
\hline \multicolumn{5}{|l|}{ Distrust } \\
\hline US & - & - & - & $-0.76^{* * *}[-0.98,-0.53]$ \\
\hline Canada & - & - & - & $-0.09[-0.41,0.24]$ \\
\hline UK & - & - & - & - \\
\hline \multicolumn{5}{|c|}{ Distrust Lead. } \\
\hline US & $0.17^{* * *}[0.08,0.25]$ & $0.13^{* * *}[0.05,0.20]$ & $0.14^{* * *}[0.06,0.22]$ & $0.13^{*}[0.00,0.25]$ \\
\hline Canada & $-0.19^{* *}[-0.33,-0.06]$ & $-0.10[-0.22,0.02]$ & $-0.16^{*}[-0.28,-0.04]$ & \\
\hline UK & $-0.25^{* * *}[-0.38,-0.12]$ & $-0.21^{* * *}[-0.32,-0.09]$ & $-0.16^{*}[-0.28,-0.03]$ & $-0.28^{* *}[-0.47,-0.09]$ \\
\hline
\end{tabular}




\begin{tabular}{|c|c|c|c|c|}
\hline Predictor & Compliance Opinion & Compliance Past & Compliance Future & Collective Action \\
\hline \multicolumn{5}{|c|}{ Health Literacy } \\
\hline US & $0.28^{* * *}[0.19,0.38]$ & $0.33^{* * *}[0.25,0.41]$ & - & $0.52^{* * *}[0.39,0.66]$ \\
\hline Canada & $0.10[-0.05,0.24]$ & $0.13[-0.00,0.26]$ & - & $0.10[-0.11,0.32]$ \\
\hline UK & - & - & - & $0.16^{*}[0.01,0.32]$ \\
\hline \multicolumn{5}{|c|}{ COVID Knowledge } \\
\hline US & $0.27^{* * *}[0.16,0.38]$ & $0.22^{* * *}[0.12,0.32]$ & - & - \\
\hline Canada & $-0.01[-0.16,0.15]$ & $-0.03[-0.17,0.11]$ & - & - \\
\hline UK & - & - & - & - \\
\hline
\end{tabular}

Note . Auth = authoritarianism; SDO = social dominance orientation; Lib-Cons = political liberalism vs. conservatism; BiS = belief in science. Simple slopes were calculated in the cases of significant interaction effects for regression models, which used the US context as a baseline. Cases without significant interactions are labeled as - Each predictor was examined separately, controlling for gender, religion, education, and ethnicity. ${ }^{*} p<.05 .{ }^{* *} p<.01 .{ }^{* * *} p<.001$.

\section{Ideology as Predictors}

Greater authoritarianism predicted less support for COVID-19 measures and less future compliance (Hypothesis 1). Significant interactions and simple slopes also revealed that the negative relations between authoritarianism with compliance opinion and future compliance were significant in the U.S., but not Canada. Moreover, although authoritarianism did not predict collective action overall, it predicted less collective action in the US sample. Across countries, people higher in SDO were less supportive of COVID-19 measures, less compliant in the past, and anticipated future (Hypothesis 2). There was also a significant interaction; simple slope analyses revealed that these relations were stronger in the US than Canadian sample. Contrary to Hypothesis 2, SDO did not predict collective action across or within counties. Hypothesis 3 was largely unsupported. Political orientation did not predict the COVID-19 variables overall. However, there were significant interactions, and simple slope analyses revealed that the positive relations between conservatism and past or future compliance were significant in the UK sample, but not American; and, political conservatism predicted less collective action in the US sample only.

\section{Collective Action Model Predictors}

Consistent with Hypothesis 4, across countries, greater empathy, efficacy, and perceiving COVID-19 as threatening predicted more support for COVID-19 measures, greater past and future compliance, and higher collective action. For compliance opinion, compliance past, and future compliance, there were also significant interactions; simple slopes showed that the positive relations were weaker or not significant (future compliance) among Canadians compared to Americans.

\section{Health and Decision-Making Variables Are Predictors}

As expected (Hypothesis 5), across countries, greater perceived local risk of COVID-19, higher personal risk, higher personal impact, higher belief in science, less distrust, and better health literacy predicted more support for COVID-19 measures, higher compliance, and higher collective action. Greater perceived severity of the risk of COVID-19 and greater COVID-19 knowledge predicted more support for measures to manage COVID-19, and compliance, but not collective action. A few significant interactions emerged, primarily those comparing the US to Canada; in every case, the simple slopes revealed the relations were weaker or not significant in Canada or the UK compared to the US. Distrust of the head of state did not significantly predict the criterion variables overall; however, simple slope analyses revealed that distrust predicted greater support, higher past and future compliance, and higher collective action in the US only, and was not significant in the UK and Canadian samples. 


\section{Discussion}

Many countries are battling a second wave of COVID-19 in late autumn 2020, and many are reintroducing additional government-mandated restrictions. Because mass adoption of behavioral measures like social distancing and handwashing will remain paramount to preventing the spread of COVID-19, health compliance emerges as a collective action in the context of a pandemic. Consequently, collective action literature can inform COVID-19-related opinions and health compliance. Consistent with recent work showing ideology motivates collective action (Choma et al., 2020; Jost et al., 2017; Osborne et al., 2019), our findings suggest that COVID-19 compliance-related attitudes and behaviors are partially driven by politics. Most consistent of the ideology measures, those higher in SDO were less supportive of efforts to manage COVID-19, less compliant with health precautions in the previous week, and expected to be less compliant in the future (Hypothesis 2). The link between SDO and support for COVID-19 measures was stronger among Americans (vs. Canadians), perhaps attributable to the larger political divide in the US (Mason, 2018).

The findings for authoritarianism and political orientation partially supported Hypotheses 1 and 3. Authoritarianism was tied to less support of endeavors to curb the spread of COVID-19, less willingness to take precautions in the future, and less interest in collective action as expected, but these effects emerged in the US sample only. Political conservatism did not emerge as a consistent predictor across countries, and unexpectedly, was connected to greater past and future compliance in the UK. Notably, unlike his US conservative counterpart (President Trump), British Prime Minister Johnson urged people to stay home or socially distance. Further, on 27 March, it was announced that Johnson tested positive for COVID-19, the same day that UK data collection began. It is possible that the positive associations in the UK reflect peoples' tendency to follow cues from their political group leader, and for those higher in political conservatism to support the system (Jost et al., 2017; Osborne et al., 2019). Supporting this speculation, the relations between distrust of head of state with compliance-related attitudes and behavior in the UK mimic those in the Canadian (with a liberal-leaning Prime Minister) rather than the US, and the time frame (late March) also corresponds to increases in behavioral compliance among British adults (YouGov, 2020). These findings speak to the relevance of context in the link between political ideologies and collective actions (Choma et al., 2020).

Literature on collective action also identifies empathy, efficacy, and threat as motivators of collective action, and in several models, they mediate links between identity or ideology and collective action (e.g. Choma et al., 2020; Jost et al., 2017; Osborne et al., 2019; van Zomeren et al., 2008). Similar to previous research, feeling greater threat associated with COVID-19, being concerned for those affected by COVID-19, and believing that collectively people can slow the spread of COVID-19 and save lives, all led to more support for COVID-19 measures, greater compliance, and higher collective action. These relations were stronger among Americans (vs. Canadians; however, there were no differences for collective action), suggesting again that the polarized US political climate may be implicated.

Empathy and efficacy especially accounted for impressive amounts of variance in opinions about measures to manage COVID-19 and compliance, as well as noteworthy variance in collective action. Thus, empathy and group efficacy seem particularly important in motivating the opinions, intentions, and behaviors necessary to curb COVID-19. Our findings also showed that those higher in SDO were less likely to experience empathy or efficacy. These findings are consistent with rich literatures identifying group efficacy as a key force driving collective action and (low) empathy as central to SDO (Hodson, 2008; Klandermans, 1984; McFarland, 2010; Mummendey et al., 1999; Sidanius et al., 2013; van Zomeren et al., 2008) and collective action (Choma et al., 2020). It also supports research showing that those higher in SDO fail to perceive a common fate - which is likely connected with empathy and group efficacy - with others (Ho et al., 2017; McFarland et al., 2019; see also Ho \& Kteily, 2020).

Variables known to impact health decision-making or behaviors (Brewer et al., 2007; Gilles et al., 2011; Kim et al., 2008; Slovic, 1987; Volk et al., 2016) also informed COVID-19-related opinions, intentions, or behaviors (Hypothesis 5). Perceiving COVID-19 as a greater personal, local, or severe risk, or the potential to impact the person, were all tied to support of efforts to curb COVID-19, compliance, or collective action. These results mirror the findings for perceived threat of COVID-19, and polls showing that perceiving COVID-19 as threatening relate to following social distance guidelines (Angus Reid Institute, 2020; Opinium, 2020; van Green \& Tyson, 2020). Participants who had stronger beliefs in science, were more health literate, and possessed more knowledge about COVID-19 supported measures to manage the spread of COVID-19 more, followed health guidelines more, and/or intended to get involved in relevant collective 
actions. Thus, public education campaigns could have some success. Trusting health authorities related positively to all the COVID-19 variables. Similar to the other relations examined presently, many of the associations between the health and decision-making variables and the COVID-19 variables were stronger in the US context compared to Canada or the UK.

Speaking to the somewhat unique American context, distrust of the head of state was not a significant predictor across samples, and instead the direction of the relation varied by country. Distrust of Prime Minsters Johnson in the UK and Trudeau in Canada predicted less support of measures to manage COVID-19, less compliance, and less collection action. In contrast, distrust of President Trump predicted more support, more compliance, and more collective action. As outlined above, the differences across countries might be attributed to the particularly polarized context in the US and the divergent messages and approaches adopted by the respective heads of state: Johnson and Trudeau encouraged people early on to adopt health compliance behaviors while Trump, during the time of data collection, downplayed the threat of COVID-19.

In terms of factors that emerged as the strongest motivators, belief in science and personal impact accounted for the most variance among the health and decision-making domain variables. Nonetheless, empathy or group efficacy still accounted for more variance and emerged as more consistent predictors across the compliance-related attitudes and behaviors, lending credence to the idea that the collective action literature might inform health compliance in the context of pandemics.

Some limitations should be considered. First, authoritarianism was measured using two items from the traditionalism subscale of Duckitt et al's (2010) ACT scale because of poor reliability. This prompted us to question whether employing items from the three subscales reflected the construct as intended. The lower reliability emerged in all three countries, suggesting the problem is likely not the scale per se, but how the items were interpreted. We suspect that the underlying message of the authoritarian submission items, which refer to adhering to "leaders in unity", and the authoritarian aggression items, which refer to "stricter laws" and "preserving law and order", may have been supported from people across the political spectrum during the time of data collection. That is, most people at that time may have desired people obey the rules. Consistent with this notion, the means on the compliance measures were high. Contrary to the other two subscales, the traditionalism subscale referred to specific content (abortion, pornography, premarital sex), and as such, may have been less malleable. Emerging research measuring ideology in the context of COVID-19 will be well positioned to further inform this possibility.

Second, political orientation was measured on a single continuum. Divergent and possibly stronger associations may have emerged with the COVID-19 variables and political orientation if we employed a bi-dimensional measure (social, economic) or group-based measures. The pattern of associations may also vary by country, with the social dimension emerging as more relevant in a US context, similar to authoritarianism (which captures the social/cultural dimension of ideological beliefs, Duckitt, 2001). Future research could explore this possibility.

Third, we focused on behaviors recommended by health authorities at the time of data collection. At that time, wearing a mask was not widely advised and hotly debated, with many health authorities (e.g. WHO) referencing concerns about a false sense of security. Since then, most health authorities have recommended people wear masks in places where social distancing is not possible. Moving forward, researchers may wish to focus on a broader range of behaviors while acknowledging possible differences between officially mandated, advised, or not recommended protocols or behaviors. Such behaviors and compliance rates are likely to be affected by local social and political contexts, as well as psychological and ideological factors. For example, in mid-June 2020 Republicans in the U.S. were more comfortable than Democrats with behaviors where social distancing is difficult, such as visiting a friend or family inside their home or eating in a restaurant (PEW, 2020). Yet, even in later June 2020, Americans across the political spectrum reported wearing a face covering in public in the previous week (99\% of Democrats, $79 \%$ of Republicans) (Karson, 2020).

Even with viable vaccines on the horizon, COVID-19 will continue to pose real threat for months, possibly years, to come, especially to lower- and middle-income nations (WHO, 2020b). Barring viable medical treatments or widely accessible vaccines, the main way to reduce contagion and save lives is through behavioral change on an unparalleled collective scale. The present findings, from three countries, with different healthcare systems, political landscapes, and COVID-19 circumstances, all highlight political ideology (especially SDO), empathy, and group efficacy, as factors to 
target in motivating people to engage in actions that curb the spread of COVID-19. These findings could also help inform how governments and organisations might encourage people to comply with health guidelines, not only for COVID-19, but future inevitable pandemics. Specifically, they might emphasize concern for those affected and a belief that collective change can make a difference to motivate continued collective action to tackle the pandemic.

Funding: This research was supported by an Insight Grant from the Social Sciences and Humanities Research Council (SSHRC) awarded to Becky Choma and Gordon Hodson.

Competing Interests: The authors have declared no competing interests exist.

Acknowledgments: We would like to thank Isabella Lam for her invaluable support in preparing study materials, creating tables, and reviewing the manuscript for errors.

Data Availability: For this article, a dataset is freely available (Choma, Hodson, Sumantry, Hanoch, \& Gummerum, 2021c).

\section{Supplementary Materials}

The following Supplementary Materials for this study are available on the Open Science Framework (OSF) (for access see Index of Supplementary Materials below):

- Preregistration protocol

- Preregistration amendment

- Data and R code

- Appendices

\section{Index of Supplementary Materials}

Choma, B. L., Hodson, G., Sumantry, D., Hanoch, Y., \& Gummerum, M. (2021a). Supplementary materials to "Ideological and psychological predictors of COVID-19-related collective action, opinions, and health compliance across three nations" [Preregistration protocol]. OSF. https://osf.io/ua4e6

Choma, B. L., Hodson, G., Sumantry, D., Hanoch, Y., \& Gummerum, M. (2021b). Supplementary materials to "Ideological and psychological predictors of COVID-19-related collective action, opinions, and health compliance across three nations" [Preregistration amendment]. OSF. https://osf.io/yqfte

Choma, B. L., Hodson, G., Sumantry, D., Hanoch, Y., \& Gummerum, M. (2021c). Supplementary materials to "Ideological and psychological predictors of COVID-19-related collective action, opinions, and health compliance across three nations" [Data and code]. OSF. https://osf.io/jxka5

Choma, B. L., Hodson, G., Sumantry, D., Hanoch, Y., \& Gummerum, M. (2021d). Supplementary materials to "Ideological and psychological predictors of COVID-19-related collective action, opinions, and health compliance across three nations" [Appendices]. OSF. https://osf.io/fhu7a

\section{References}

Altemeyer, R. A. (1981). Right-wing authoritarianism. Winnipeg, Manitoba, Canada: University of Manitoba Press.

Angus Reid Institute (ARI). (2020, March 30). COVID-19 carelessness: Which Canadians say pandemic threat is 'overblown'? And how are they behaving in turn? Retrieved from http://angusreid.org/covid-19-serious-vs-overblown

Batson, C. D., Polycarpou, M. P., Harmon-Jones, E., Imoff, H. J., Mitchener, E. C., Bednar, L., . . Highberger, L. (1997). Empathy and attitudes: Can feeling for a member of a stigmatized group improve feelings toward the group? fournal of Personality and Social Psychology, 72, 105-118. https://doi.org/10.1037/0022-3514.72.1.105

Baumgaertner, B., Carlisle, J. E., \& Justwan, F. (2018). The influence of political ideology and trust on willingness to vaccinate. PLoS One, 13(1), Article e0191728. https://doi.org/10.1371/journal.pone.0191728 
Becker, J. C. (2020). Ideology and the promotion of social change. Current Opinion in Behavioral Sciences, 34, 6-11. https://doi.org/10.1016/j.cobeha.2019.10.005

Bendik, M. K., Mayo, R. M., \& Parker, V. G. (2011). Knowledge, perceptions, and motivations related to HPV vaccination among college women. Journal of Cancer Education, 26(3), 459-464. https://doi.org/10.1007/s13187-011-0200-8

Bliuc, A. M., McGarty, C., Reynolds, K., \& Muntele, D. (2007). Opinion-based group membership as a predictor of commitment to collective action. European fournal of Social Psychology, 37, 19-32. https://doi.org/10.1002/ejsp.334

Borràs, E., Domínguez, À., Fuentes, M., Batalla, J., Cardeñosa, N., \& Plasencia, A. (2009). Parental knowledge of paediatric vaccination. BMC Public Health, 9(1), Article 154. https://doi.org/10.1186/1471-2458-9-154

Brewer, N. T., Chapman, G. B., Gibbons, F. X., Gerrard, M., McCaul, K. D., \& Weinstein, N. D. (2007). Meta-analysis of the relationship between risk perception and health behavior: The example of vaccination. Health Psychology, 26(2), 136-145. https://doi.org/10.1037/0278-6133.26.2.136

Choma, B. L., Hanoch, Y., Gummerum, M., \& Hodson, G. (2013). Relations between risk perceptions and socio-political ideology are domain-and ideology-dependent. Personality and Individual Differences, 54(1), 29-34. https://doi.org/10.1016/j.paid.2012.07.028

Choma, B. L., Hodson, G., Jagayat, A., \& Hoffarth, M. R. (2020). Right-wing ideology as a predictor of collective action: A test across four political issue domains. Political Psychology, 41, 303-322. https://doi.org/10.1111/pops.12615

Crosby, F. J. (1976). A model of egoistical relative deprivation. Psychological Review, 83, 85-113. https://doi.org/10.1037/0033-295X.83.2.85

Duckitt, J. (2001). A dual process cognitive-motivational theory of ideology and prejudice. In M. Zanna (Ed.), Advances in Experimental Social Psychology (Vol. 33, pp. 41-113). San Diego, CA, USA: Academic Press.

Duckitt, J., Bizumic, B., Krauss, S. W., \& Heled, E. (2010). A tripartite approach to right-wing authoritarianism: The authoritarianismconservatism-traditionalism model. Political Psychology, 31(5), 685-715. https://doi.org/10.1111/j.1467-9221.2010.00781.x

Duckitt, J., \& Sibley, C. G. (2009). A dual-process motivational model of ideology, politics, and prejudice. Psychological Inquiry, 20, 98-109. https://doi.org/10.1080/10478400903028540

Duckitt, J., \& Sibley, C. G. (2017). The dual process motivational model of ideology and prejudice. In C. G. Sibley \& F. K. Barlow (Eds.), The Cambridge handbook of the psychology of prejudice (pp. 188-220). Cambridge, United Kingdom: Cambridge University Press.

Farias, M., Newheiser, A. K., Kahane, G., \& de Toledo, Z. (2013). Scientific faith: Belief in science increases in the face of stress and existential anxiety. Journal of Experimental Social Psychology, 49(6), 1210-1213. https://doi.org/10.1016/j.jesp.2013.05.008

Faul, F., Erdfelder, E., Buchner, A., \& Lang, A.-G. (2009). Statistical power analyses using G*Power 3.1: Tests for correlation and regression analyses. Behavior Research Methods, 41, 1149-1160. https://doi.org/10.3758/BRM.41.4.1149

Fernandez, D. M., Larson, J. L., \& Zikmund-Fisher, B. J. (2016). Associations between health literacy and preventive health behaviors among older adults: Findings from the health and retirement study. BMC Public Health, 16(1), Article 596. https://doi.org/10.1186/s12889-016-3267-7

Foster, M. D., \& Matheson, K. (1995). Double relative deprivation: Combining the personal and political. Personality and Social Psychology Bulletin, 21, 1167-1177. https://doi.org/10.1177/01461672952111005

Gauchat, G. (2012). Politicization of science in the public sphere: A study of public trust in the United States, 1974 to 2010. American Sociological Review, 77(2), 167-187. https://doi.org/10.1177/0003122412438225

Gelman, A., \& Hill, J. (2006). Data analysis using regression and multilevel/hierarchical models. Cambridge, United Kingdom: Cambridge University Press.

Gilles, I., Bangerter, A., Clémence, A., Green, E. G., Krings, F., Staerklé, C., \& Wagner-Egger, P. (2011). Trust in medical organizations predicts pandemic (H1N1) 2009 vaccination behavior and perceived efficacy of protection measures in the Swiss public. European fournal of Epidemiology, 26(3), 203-210. https://doi.org/10.1007/s10654-011-9577-2

Hamilton, L. C., Hartter, J., \& Saito, K. (2015). Trust in scientists on climate change and vaccines. SAGE Open, 5(3), Article 2158244015602752. https://doi.org/10.1177/2158244015602752

Ho, A. K., \& Kteily, N. (2020). The role of group-based egalitarianism in collective action. Current Opinion in Psychology, 35, $108-113$. https://doi.org/10.1016/j.copsyc.2020.05.009

Ho, A. K., Kteily, N., \& Chen, J. M. (2017). "You're one of us”: Black Americans' use of hypodescent and its association with egalitarianism. Journal of Personality and Social Psychology, 113, 753-768. https://doi.org/10.1037/pspi0000107 
Ho, A. K., Sidanius, J., Kteily, N., Sheehy-Skeffington, J., Pratto, F., Henkel, K. E., . . Stewart, A. L. (2015). The nature of social dominance orientation: Theorizing and measuring preferences for intergroup inequality using the new SDO7 scale. Fournal of Personality and Social Psychology, 109, 1003-1028. https://doi.org/10.1037/pspi0000033

Hodson, G. (2008). Interracial prison contact: The pros for (socially dominant) cons. British fournal of Social Psychology, 47(2), 325-351. https://doi.org/10.1348/014466607X231109

Ibuka, Y., Chapman, G. B., Meyers, L. A., Li, M., \& Galvani, A. P. (2010). The dynamics of risk perceptions and precautionary behavior in response to 2009 (H1N1) pandemic influenza. BMC Infectious Diseases, 10(1), Article 296. https://doi.org/10.1186/1471-2334-10-296

Jost, J. T., Becker, J., Osborne, D., \& Badaan, V. (2017). Missing in (collective) action: Ideology, system justification, and the motivational antecedents of two types of protest behavior. Current Directions in Psychological Science, 26, 99-108. https://doi.org/10.1177/0963721417690633

Jost, J. T., Glaser, J., Kruglanski, A. W., \& Sulloway, F. J. (2003). Political conservatism as motivated social cognition. Psychological Bulletin, 129(3), 339-375. https://doi.org/10.1037/0033-2909.129.3.339

Karson, K. (2020, June 25). 89\% of Americans wear masks in public as coronavirus pandemic Persists: Poll. ABC News. Retrieved from https://abcnews.go.com/Politics/89-americans-wear-masks-public-coronavirus-pandemic-persists/story?id=71455062

Keele, L. (2005). The authorities really do matter: Party control and trust in government. The fournal of Politics, 67(3), 873-886. https://doi.org/10.1111/j.1468-2508.2005.00343.x

Kim, S. E., Pérez-Stable, E. J., Wong, S., Gregorich, S., Sawaya, G. F., Walsh, J. M., \& Kaplan, C. P. (2008). Association between cancer risk perception and screening behavior among diverse women. Archives of Internal Medicine, 168(7), 728-734. https://doi.org/10.1001/archinte.168.7.728

Klandermans, B. (1984). Mobilization and participation: Social psychological expansions of resource mobilization theory. American Sociological Review, 49(5), 583-600. https://doi.org/10.2307/2095417

Krause, R. M., Carley, S. R., Warren, D. C., Rupp, J. A., \& Graham, J. D. (2014). "Not in (or under) my backyard”: Geographic proximity and public acceptance of carbon capture and storage facilities. Risk Analysis, 34(3), 529-540. https://doi.org/10.1111/risa.12119

Lai, S., Bogoch, I. I., Ruktanonchai, N., Watts, A. G., Li, Y., Yu, J., ... Li, Z. (2020). Assessing spread risk of Wuhan novel coronavirus within and beyond China, January-April 2020: A travel network-based modelling study. medRxiv. https://doi.org/10.1101/2020.02.04.20020479

Levy, H., \& Janke, A. (2016). Health literacy and access to care. Journal of Health Communication, 21(Supp. 1), 43-50. https://doi.org/10.1080/10810730.2015.1131776

Mason, L. (2018). Uncivil agreement: How politics became our identity. Chicago, IL, USA: The University of Chicago Press.

McCright, A. M., Dentzman, K., Charters, M., \& Dietz, T. (2013). The influence of political ideology on trust in science. Environmental Research Letters, 8(4), Article 044029. https://doi.org/10.1088/1748-9326/8/4/044029

McFarland, S. (2010). Authoritarianism, social dominance orientation and other roots of generalized prejudice. Political Psychology, 31, 453-477. https://doi.org/10.1111/j.1467-9221.2010.00765.x

McFarland, S., Hackett, J., Hamer, K., Katzarska-Miller, I., Malsch, A., Reese, G., \& Reysen, S. (2019). Global human identification and citizenship: A review of psychological studies. Political Psychology, 40,141-171. https://doi.org/10.1111/pops.12572

Miller, T. A. (2016). Health literacy and adherence to medical treatment in chronic and acute illness: A meta-analysis. Patient Education and Counseling, 99(7), 1079-1086. https://doi.org/10.1016/j.pec.2016.01.020

Mummendey, A., Kessler, T., Klink, A., \& Mielke, R. (1999). Strategies to cope with negative social identity: Predictions by social identity theory and relative deprivation theory. Fournal of Personality and Social Psychology, 76(2), 229-245.

https://doi.org/10.1037/0022-3514.76.2.229

Onraet, E., Dhont, K., \& Van Hiel, A. (2014). The relationships between internal and external threats and right-wing attitudes: A threewave longitudinal study. Personality and Social Psychology Bulletin, 40, 712-725. https://doi.org/10.1177/0146167214524256

Opinium. (2020, March 19). Public opinion on coronavirus - March 19. Retrieved from https://www.opinium.co.uk/public-opinion-on-coronavirus-19th-march-2020

Osborne, D., Jost, J. T., Becker, J. C., Badaan, V., \& Sibley, C. G. (2019). Protesting to challenge or defend the system? A system justification perspective on collective action. European fournal of Social Psychology, 49, 244-269. https://doi.org/10.1002/ejsp.2522 
Osborne, D., Yogeeswaran, K., \& Sibley, C. G. (2017). Culture-specific ideologies undermine collective action support: Examining the legitimizing effects of postcolonial belief systems. Group Processes \& Intergroup Relations, 20, 333-349. https://doi.org/10.1177/1368430216682352

PEW Research Center. (2020, June 25). Republicans, democrats move even further apart in Coronavirus concerns. Retrieved from https://www.pewresearch.org/politics/2020/06/25/republicans-democrats-move-even-further-apart-in-coronavirus-concerns

Pratto, F., Sidanius, J., Stallworth, L. M., \& Malle, B. F. (1994). Social dominance orientation: A personality variable predicting social and political attitudes. Fournal of Personality and Social Psychology, 67(4), 741-763. https://doi.org/10.1037/0022-3514.67.4.741

Richtering, S. S., Hyun, K., Neubeck, L., Coorey, G., Chalmers, J., Usherwood, T., . . Redfern, J. (2017). eHealth literacy: Predictors in a population with moderate-to-high cardiovascular risk. FMIR Human Factors, 4(1), Article e4. https://doi.org/10.2196/humanfactors.6217

Rolison, J. J., \& Hanoch, Y. (2015). Knowledge and risk perceptions of the Ebola virus in the United States. Preventive Medicine Reports, 2, 262-264. https://doi.org/10.1016/j.pmedr.2015.04.005

Rutjens, B. T., Heine, S. J., Sutton, R. M., \& van Harreveld, F. (2018). Attitudes towards science. In Advances in Experimental Social Psychology (Vol. 57, pp. 125-165). Cambridge, United Kingdom: Academic Press.

Saeri, A. K., Iyer, A., \& Louis, W. R. (2015). Right-wing authoritarianism and social dominance orientation predict outsiders' responses to an external group conflict: Implications for identification, anger, and collective action. Analyses of Social Issues and Public Policy, 15, 303-332. https://doi.org/10.1111/asap.12081

Safford, T. G., Hamilton, L. C., \& Whitmore, E. (2017, Spring). The Zika virus threat: How concerns about scientists may undermine efforts to combat the pandemic. Carsey Research (Regional Issue \#49 Brief). Retrieved from https://core.ac.uk/download/pdf/84123618.pdf

Shaffer, B., \& Duckitt, J. (2013). The dimensional structure of people's fears, threats, and concerns and their relationship with rightwing authoritarianism and social dominance orientation. International fournal of Psychology, 48, 6-17. https://doi.org/10.1080/00207594.2012.696651

Sidanius, J., Kteily, N., Sheehy-Skeffington, J., Ho, A. K., Sibley, C., \& Duriez, B. (2013). You're inferior and not worth our concern: The interface between empathy and social dominance orientation. fournal of Personality, 81, 313-323. https://doi.org/10.1111/jopy.12008

Slovic, P. (1987). Perception of risk. Science, 236(4799), 280-285. https://doi.org/10.1126/science.3563507

Tajfel, H., \& Turner, J. C. (1979). An integrative theory of inter-group conflict. In W. G. Austin \& S. Worchel (Eds.), The social psychology of inter-group relations (pp. 33-47). Monterey, CA, USA: Brooks/Cole.

Taylor, D. B. (2020, April 28). How the coronavirus pandemic unfolded: A timeline. The New York Times. Retrieved from https://www.nytimes.com/article/coronavirus-timeline.html

Thomas, E. F., Mavor, K. I., \& McGarty, C. (2012). Social identities facilitate and encapsulate action-relevant constructs: A test of the social identity model of collective action. Group Processes \& Intergroup Relations, 15(1), 75-88.

https://doi.org/10.1177/1368430211413619

Thomas, E. F., McGarty, C., \& Mavor, K. I. (2009). Aligning identities, emotions, and beliefs to create commitment to sustainable social and political action. Personality and Social Psychology Review, 13(3), 194-218. https://doi.org/10.1177/1088868309341563

van der Weerd, W., Timmermans, D. R., Beaujean, D. J., Oudhoff, J., \& van Steenbergen, J. E. (2011). Monitoring the level of government trust, risk perception and intention of the general public to adopt protective measures during the influenza A (H1N1) pandemic in the Netherlands. BMC Public Health, 11(1), Article 575. https://doi.org/10.1186/1471-2458-11-575

van Green, T. V., \& Tyson, A. (2020, April 2). 5 facts about partisan reactions to COVID-19. Pew Research Center. Retrieved from https://www.pewresearch.org/fact-tank/2020/04/02/5-facts-aboutpartisan-reactions-to-covid-19-in-the-u-s

van Zomeren, M., Postmes, T., Spears, R., \& Bettache, K. (2011). Can moral convictions motivate the advantaged to challenge social inequality? Extending the social identity model of collective action. Group Processes \& Intergroup Relations, 14, 735-753. https://doi.org/10.1177/1368430210395637

Villarreal, A. (2020, May 28). Four months and 100,000 deaths: The defining COVID-19 moments in the US - Timeline. The Guardian. https://www.theguardian.com/us- news/2020/apr/25/us-coronavirus-timeline-trump-cases-deaths

Volk, R. J., Linder, S. K., Lopez-Olivo, M. A., Kamath, G. R., Reuland, D. S., Saraykar, S. S., . . Pignone, M. P. (2016). Patient decision aids for colorectal cancer screening: A systematic review and meta-analysis. American fournal of Preventive Medicine, 51, 779-791. https://doi.org/10.1016/j.amepre.2016.06.022 
Wee, S., \& McNeill, D. G. (2020, January 21). China identifies new virus causing pneumonialike illness. The New York Times. Retrieved from https://www.nytimes.com/2020/01/08/health/china-pneumonia-outbreak-virus.html

Weiner, E., \& Federico, C. M. (2017). Authoritarianism, institutional confidence, and willingness to engage in collective action: A multinational analysis. Personality and Social Psychology Bulletin, 43(3), 392-406. https://doi.org/10.1177/0146167216686561

World Health Organization (WHO). (2020a, April 17). Q\&A on coronaviruses (COVID-19). Retrieved from https:/www.who.int/news-room/q-a-detail/q-a-coronaviruses

World Health Organization (WHO). (2020b, December 3). Global equitable access to COVD-19 vaccines estimated to generate economic benefits of at least US\$ 153 billion in 2020-21, and US\$ 466 billion by 2025, in 10 major economies, according to new report by the Eurasia group. Retrieved from

https:/www.who.int/news/item/03-12-2020-global-access-to-covid-19-vaccines-estimated-to-generate-economic-benefits-of-atleast-153-billion-in-2020-21

Wright, S. C., Taylor, D. M., \& Moghaddam, F. M. (1990). Responding to membership in a disadvantaged group: From acceptance to collective protest. Journal of Personality and Social Psychology, 58, 994-1003. https://doi.org/10.1037/0022-3514.58.6.994

YouGov. (2020). YouGov international COVID-19 tracker [Data set]. YouGov. Retrieved from https://yougov.co.uk/topics/international/articles-reports/2020/03/17/YouGov-international-COVID-19-tracker

van Zomeren, M. (2013). Four core social-psychological motivations to undertake collective action. Social and Personality Psychology Compass, 7(6), 378-388. https://doi.org/10.1111/spc3.12031

van Zomeren, M., Postmes, T., \& Spears, R. (2008). Toward an integrative social identity model of collective action: A quantitative research synthesis of three socio-psychological perspectives. Psychological Bulletin, 134(4), 504-535. https://doi.org/10.1037/0033-2909.134.4.504

Zhong, R., \& Mozur, P. (2020, February 20). To tame coronavirus, Mao-style social control blankets China. The New York Times. Retrieved from https://www.nytimes.com/2020/02/15/business/china-coronavirus-lockdown.html 